\title{
Pregnancy Diagnosis in the Surti Goat by Trans-Rectal Ultrasound Scanning and Progesterone Estimation
}

\author{
M. M. Chaudhary*, C. T. Khasatiya, N. F. Chaudhari, L. C. Modi and V. B. Atara \\ Department of Veterinary Gynaecology and Obstetrics, College of Veterinary Science \\ and A. H., Navsari Agricultural University, Navsari, India \\ *Corresponding author
}

Keywords

Goat, Progesterone, Ultrasonography

Article Info

\section{Accepted:}

12 April 2021

Available Online:

10 May 2021

\section{A B S T R A C T}

Total eighteen Surti goats were selected in the present study. The aim of the present study was to diagnose pregnancy at 40 days after breeding in selected goats by trans-rectal ultrasound scanning and progesterone assay simultaneously. Out of eighteen Surti goats, 17 (94.44\%) goats were detected at pregnant by trans-rectal ultrasound scanning. On the same day of scanning, blood samples were collected from all the goats to estimate progesterone concentration. The mean serum progesterone concentration was $6.54 \pm 0.42 \mathrm{ng} / \mathrm{ml}$ on 40 days of pregnancy in pregnant goats $(\mathrm{n}=17)$ as compared to $2.49 \mathrm{ng} / \mathrm{ml}$ in non-pregnant goat $(\mathrm{n}=1)$.

\section{Introduction}

Pregnancy detection in the goat can be detected by several techniques. Among them, real-time ultrasound scanning and estimation of serum progesterone are two very important and accurate methods. Both the methods have their own advantages and limitations. Although several studies have been carried out to evaluate each of these different methods individually, it is difficult to establish adequate comparisons between them due to different factors. The present study was conducted to diagnose pregnancy at 40 days after breeding in Surti goats by trans-rectal ultrasound scanning and its further confirmation by estimation of serum progesterone concentration.

\section{Materials and Methods}

Total eighteen Surti does managed under uniform managerial farm conditions were selected to diagnose pregnancy at 40 days after breeding by trans-rectal ultrasound scanning and progesterone assay simultaneously.

Trans-rectal ultrasound examinations were performed at 40 days after breeding with a $6.5 \mathrm{MHz}$ B-mode linear transducer. To estimate serum progesterone, $5 \mathrm{ml}$ blood was 
collected aseptically by jugular vein puncture from all the selected goats on the same day. The serum was separated by standard procedure and stored in the deep freeze at $-20^{\circ} \mathrm{C}$ till further analysis. Serum progesterone $\left(\mathrm{P}_{4}\right)$ concentration was measured by standard Enzyme Linked Immunosorbent Assay (ELISA) technique using assay kits and procedure described by Diagnostic Automation/Cortez Diagnostics, Inc., California, USA.

\section{Results and Discussion}

\section{Pregnancy Diagnosis by Serum} Progesterone $\left(\mathbf{P}_{4}\right)$ Concentration

The mean serum progesterone concentration at 40 days post service was $6.54 \pm 0.42 \mathrm{ng} / \mathrm{ml}$ on 40 days of pregnancy in pregnant goats $(n=17)$ which was in accordance with Islam et al., (2013). The accuracy of pregnancy by progesterone estimation by ELISA at 40 days of pregnancy was 100 per cent in present finding which was in accordance with Pati $e t$ al., (2015) in progesterone estimation carried out by radio-immunoassay technique in Osmanabadi goat. While, accuracy was lower $(37.5 \%)$ by radio-immunoassay technique in

Fig.1 Live foetus in the amniotic sac with heart beat

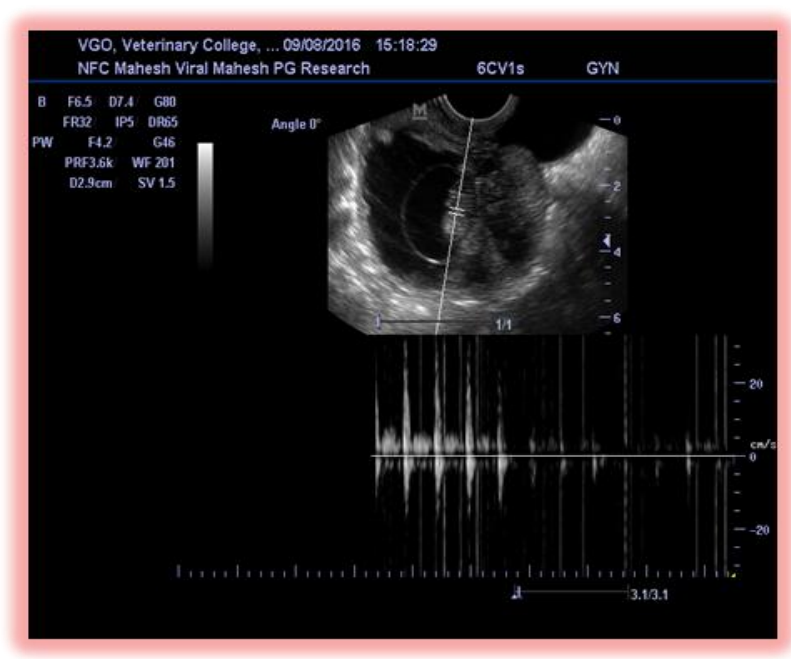

Nubian goat (Ahmed et al., 1998); 80\% in Shiba goat on day 21 after mating (Medan et al., 2004) and $82 \%$ in dairy goat (Engeland $e t$ al., 1997).

\section{Pregnancy Diagnosis by Ultrasonography}

Ultrasonography was carried out on day - 40 post breeding with a $6.5 \mathrm{MHz} \mathrm{B}$-mode linear transducer (Fig. 1 and 2). In the present finding, accuracy of pregnancy and nonpregnancy were 100 per cent in accordance with Deokate et al., (2007) in Osmanabadi does, Omontese et al., (2012) in Red Soketo does of Nigeria and Badawi et al., (2014) in Nubian goat.

The trans-abdominal and trans-rectal scanning technique are used to diagnose pregnancy in goats. Trans-abdominal scanning of goats, performed between days 40 and 70 after mating, yields information about pregnancy, fetal viability and single or multiple pregnancy, while at the same time making possible a reliable differential diagnosis of pregnancy and hydrometra reported by Hesselink and Taverne (1994) in local breeds of goat.

Fig.2 Twin foetuses in amniotic sac by transrectal ultrasonography on $40^{\text {th }}$ day of pregnancy

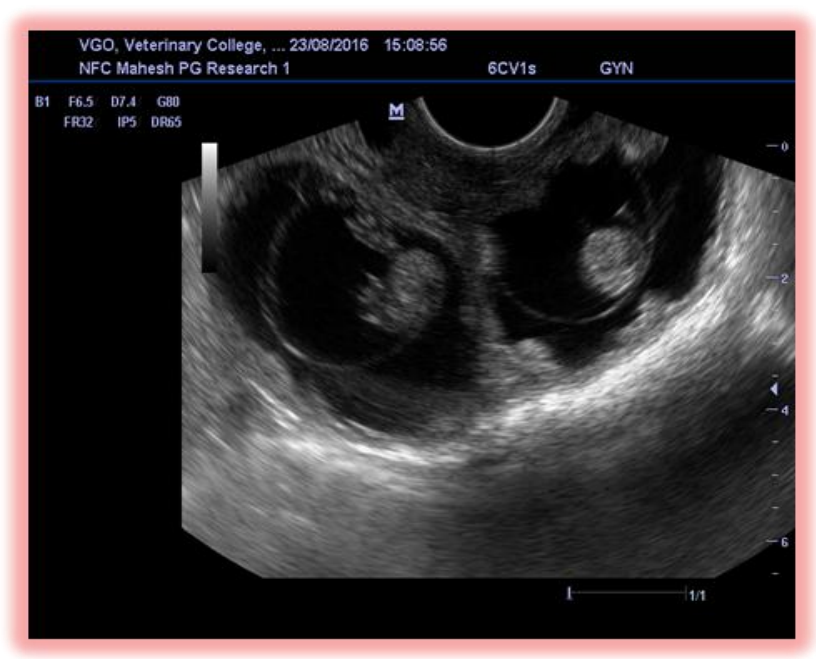


Embryo proper and heart beat were detected by 42 to 45 days of gestation using B-mode real time trans-rectal ultrasonography in goat reported by Agrawal et al., (2006) in nondescript goat. Observation and identification of sac, non-echogenic area and foetus, foetal heart, uterine wall, amniotic fluid were detected from days 21 to 49 of gestation also reported by Raja-Khalif et al., (2014) in Jermasia and crossbred Boer does. B mode real time ultrasonography can be employed to develop database of fetal development in goats which can serve as reference value for detecting any abnormal development of kids in uterus (Kumar et al., 2005).

Based on the present findings it can be concluded that trans-rectal ultrasonography provides an appropriate alternative to progesterone estimation for detection of pregnancy on day 40 post breeding in goat.

\section{References}

Agrawal, S. K., Suguna, K., Hoque, M., Mehrotra., Singh. S. K. and Umashankar (2006). Early pregnancy diagnosis using ultrasonography in goat. XXII Annual Convention of ISSAR \& National Symposium; Nov.10-12, Vet. Coll. Mhow. (M.P), pp.31.

Ahmed, M. M. M., Makawi, S. E. and Jubara, A. S. (1998). Synchronization of oestrus in Nubian goats. Small Ruminant Research, 30: 113-120.

Badawi, M. E., Makawi, S. E. A., Abdelghafar, R. M. and Ibrahim, M. T. (2014). Effect of Oestrous Synchronization using PGF2 $\alpha$ on Subsequent Fertility of Nubian Goats (Capra hircus). Journal of Agricultural and Veterinary Sciences, 15(2): 45-53.

Deokate, K. R., Dhoble, R. L., Gaikwad, S. M., Sawale, A. G. and Juvekar, J. C.
(2007). B-mode real time ultrasonography for early pregnancy diagnosis in Osmanabadi goats. Indian Journal of Animal Science, 77(7): 580582.

Engeland, I. V., Ropstad, E., Andresen, O. and Eik, L. O. (1997). Pregnancy diagnosis in dairy goats using progesterone assay kits and oestrous observation. Animal Reproduction Science, 47:237-243.

Hesselink, J. W. and Taverne, M. A. M. (1994). Ultrasonography of the uterus of the goat. Veterinary Quarterly, 16(1): 41-45.

Islam, M. M., Mondal, S. K. and Patel, B. H. M. (2013). Post-Synchronization Progesterone Profile of Indigenous Goats During Early Pregnancy. Indian Veterinary Journal, 90(3): 22 - 23.

Kumar, J., Chandolia, R. K. and Verma, S. K. (2005). Ultrasonographic imaging of Early fetal development in BlackBengal goats. Indian Journal Animal Reproduction, 26(1): 39-42.

Medan, M., Watanabe, G., Absy, G., Sasaki, K., Sharawy, S. and Taya, K. (2004). Early Pregnancy Diagnosis by Means of Ultrasonography as a Method of Improving Reproductive Efficiency in Goats. Journal of Reproduction and Development, 50(4):391-396.

Omontese,B. O., Rekwot, P. I., Ate, I. U., Rwuaan, J. S., Makun, H. J., Mustapha, R. A. and Lawal, M. (2012).Use of ultrasonography for pregnancy diagnosis in red Sokoto goats. Scientific Journal of Animal Science, 1(6):192-197.

Pati, P., Sahatpure, S. K., Patil, A. D., Patil, M. S. and Gawande, A. P. (2015). Early pregnancy detection in Osmanabadi goats by Transrectal Sonography and progesterone estimation. In: XXXI Annual Convention of The Indian Society for study of Animal Reproduction 
(ISSAR) and National Symposium on Current Challenges and Opportunities in Animal Reproduction, Veterinary College, Hebbal (Bengaluru), pp. 151. Raja-Khalif, R. I. A., Rahman, M. M., Wan-
Khadijah, W. E. and Abdullah, R. B. (2014). Pregnancy diagnosis in goats by using two different ultrasound Probes. The Journal of Animal \& Plant Sciences, 24(4):1026-1031.

\section{How to cite this article:}

Chaudhary, M. M., C. T. Khasatiya, N. F. Chaudhari, L. C. Modi and Atara, V. B. 2021. Pregnancy Diagnosis in the Surti Goat by Trans-Rectal Ultrasound Scanning and Progesterone Estimation. Int.J.Curr.Microbiol.App.Sci. 10(05): 149-152.

doi: https://doi.org/10.20546/ijcmas.2021.1005.020 